\section{$\underset{\text { hommes }}{\text { \& migrations }}$}

\section{Hommes \& migrations}

Revue française de référence sur les dynamiques

migratoires

$1290 \mid 2011$

Travailleurs sociaux et migrations

\title{
Delphine Coulin, Samba pour la France
}

Seuil, 19 euros, 2011, 306 pages

\section{Élisabeth Lesne}

\section{OpenEdition \\ 1 Journals}

\section{Édition électronique}

URL : http://journals.openedition.org/hommesmigrations/778

DOI : 10.4000/hommesmigrations.778

ISSN : 2262-3353

\section{Éditeur}

Musée national de l'histoire de l'immigration

\section{Édition imprimée}

Date de publication : 1 mars 2011

Pagination : 157

ISSN : 1142-852X

\section{Référence électronique}

Élisabeth Lesne, «Delphine Coulin, Samba pour la France », Hommes \& migrations [En ligne], 1290 |

2011, mis en ligne le 29 mai 2013, consulté le 10 décembre 2020. URL : http://

journals.openedition.org/hommesmigrations/778 ; DOI : https://doi.org/10.4000/hommesmigrations. 778

Ce document a été généré automatiquement le 10 décembre 2020.

Tous droits réservés 


\title{
Delphine Coulin, Samba pour la France
}

Seuil, 19 euros, 2011, 306 pages

\author{
Élisabeth Lesne
}

\section{RÉFÉRENCE}

Delphine Coulin, Samba pour la France, Seuil, 19 euros, 2011, 306 pages

1 “Cours, Samba, cours !" lui disait son oncle Lamouna, quand il jouait avec son cerf-volant fait d'un sac plastique relié à des ficelles. C'était à une "époque où il était quelqu'un sans se poser de questions. Où il ne savait même pas qu'on pouvait n'être personne".

Depuis, Samba a quitté le Mali pour venir en France. Aussitôt son bac en poche, il a dû s'y prendre à quatre fois, mais il ignorait alors que "le voyage héroïque qu'il avait accompli serait finalement moins dur que tout ce qu'il allait vivre après son arrivée en France".

3 Le roman de Delphine Coulin commence lorsque Samba se présente spontanément à la Préfecture, sûr d'avoir droit désormais à une carte de séjour : cela fait dix ans et cinq mois qu'il vit à Paris et accepte les boulots les plus ingrats. Erreur! On l'envoie à Vincennes dans un centre de rétention, une prison secouée de cris, de larmes et de suicides, qui frémit de peur et de ravissement mêlés quand débarquent 17 travelos. Grâce à des jeunes femmes de la Cimade, il en sort libre, mais expulsable à tout moment, avec une obligation de quitter le territoire français (OQTF). Il n'aura d'autre solution que d'entrer dans la clandestinité et d'avoir recours à l'usurpation d'identité avec l'aide de son oncle, puis par vol, puis par "emprunt" après la mort accidentelle de son copain Jonas.

4 Si l'on peut lire son histoire, c'est parce qu'une bénévole de la Cimade, la narratrice, en a rassemblé les bribes. Rien d'un récit linéaire, mais des fragments comme on en livre à un ami et qui finissent par retracer toute une vie, sans que le lecteur se perde. Pas de pathos ni de misérabilisme dans ce roman qui évoque pourtant les événements terribles qui ont 
contraint l'oncle Lamouna et les Congolais Jonas et Gracieuse à s'exiler. On plonge dans les pratiques des boîtes d'intérim et du travail clandestin, avec les petits chefs qui appellent tous les Noirs "Boubou" et les ouvriers immigrés en règle qui n'aiment pas trop les sans-papiers... On découvre la vie sur les chantiers, on sent les muscles noués, on voit la jeunesse qui fout le camp à toute allure avec ces travaux de force.

Il y a également des moments de bonheur et de solidarité. D'abord, le couple que forme Samba avec son oncle dans leur cave louée à prix d'or et qui rappelle celui de Lenny et George dans Des souris et des hommes de Steinbeck. George reprochait souvent à Lenny, le géant tendre à la force inouïe, de ne lui attirer que des ennuis, mais ils se soutenaient et se racontaient la ferme qu'ils achèteraient dès qu'ils auraient amassé un peu d'argent. Les deux Maliens, eux, évoquent les maisons bleues voisines qu'ils se feront construire quand ils rentreront au pays, les plaisirs, les filles qu'ils connaitront.

6 Ensuite, son amitié pour Wilson le Colombien, avec qui Samba va retrouver Gracieuse, la femme d'un Congolais rencontré à Vincennes, et toute la tendresse de sa relation avec cette jeune femme. Enfin, sa complicité avec Georgette, une vieille femme indomptable qui va vendre à Belleville les produits périmés des supermarchés.

7 Le livre refermé, le lecteur se demande comment Geneviève Coulin, jeune romancière d'origine bretonne également cinéaste et productrice à Arte, a si bien pu se glisser dans la peau d'un Malien de 30 ans. 